\title{
Hispanics in the U.S. Labor Market A Tale of Three Generations
}

Pia M. Orrenius and Madeline Zavodny

Federal Reserve Bank of Dallas

Research Department

Working Paper 1809

https:// doi.org/10.24149/wp1809 


\title{
Hispanics in the U.S. Labor Market: A Tale of Three Generations*
}

\author{
Pia M. Orrenius \\ Federal Reserve Bank of Dallas \\ 2200 N. Pearl St. \\ Dallas, TX, 75201 \\ pia.orrenius@dal.frb.org \\ Madeline Zavodny \\ University of North Florida \\ 1 UNF Drive \\ Jacksonville, FL 32224 \\ m.zavodny@unf.edu
}

May 2018

\begin{abstract}
Immigrants' descendants typically assimilate toward mainstream social and economic outcomes across generations. Hispanics in the United States are a possible exception to this pattern. Although there is a growing literature on intergenerational progress, or lack thereof, in education and earnings among Hispanics, there is little research on employment differences across immigrant generations. Using data from 1996 to 2017, this study reveals considerable differences in Hispanics' employment rates across immigrant generations. Hispanic immigrant men tend to have higher employment rates than non-Hispanic whites and second- and third-plus generation Hispanics. Hispanic immigrant women have much lower employment rates, but employment rates rise considerably in the second generation. Nonetheless, U.S.-born Hispanic women are less likely than non-Hispanic white women to work. The evidence thus suggests segmented assimilation, in which the descendants of Hispanic immigrants have worse outcomes across generations. While relatively low education levels do not appear to hamper Hispanic immigrants' employment, they play a key role in explaining low levels of employment among Hispanic immigrants' descendants. Race and selective ethnic attrition may also contribute to some of the patterns uncovered here.
\end{abstract}

JEL classification: J11, J15, E24

Keywords: Hispanics, immigrant generations, assimilation

\footnotetext{
* We thank Marie Mora and participants at the Federal Reserve System’s Disparities in the Labor Market Conference and the 2018 Population Association of America conference as well as seminar participants at the University of Oklahoma and Louisiana State University for helpful comments on earlier versions of this paper. The views expressed here are solely those of the authors and do not reflect those of the Federal Reserve Bank of Dallas or the Federal Reserve System.
} 


\section{Introduction}

Immigrants typically converge toward mainstream economic and social outcomes across generations. In general, immigrants' children, grandchildren, and subsequent generations of descendants each more closely resemble the population average in terms of education, employment, earnings, and other outcomes than do immigrants themselves. Evidence of such intergenerational assimilation or integration is widespread across origins, destinations, and time periods. However, there are exceptions. Hispanics in the contemporary United States may be one of them. Studies have noted that the children of Hispanic immigrants have far more education than their parents, but gains in educational attainment appear to stall after the second generation. ${ }^{1}$ The average education level of third-plus generation Hispanics is well below that of nonHispanic whites.

This study examines differences in labor market outcomes across Hispanic immigrant generations. Understanding how Hispanics do in the labor market is important since more than one in six workers is Hispanic, and Hispanics account for a disproportionate share of labor force growth. Differences across immigrant generations may be important as well since a rising share of Hispanics is U.S.-born. This is the result of both smaller immigration flows from Latin America since the start of the Great Recession of 2007-2009 and, until the recession, relatively high birthrates among Hispanic immigrants living in the United States. Although a number of studies examine differences across immigrant generations in Hispanics’ or Mexican Americans’ educational attainment (e.g., Telles and Ortiz 2008; Duncan et al. 2017) and in their earnings

\footnotetext{
${ }^{1}$ Studies of Hispanics and/or Mexican Americans include Farley and Alba (2002), Grogger and Trejo (2002), Trejo (2003), Duncan, Hotz, and Trejo (2006), Blau and Kahn (2007), Telles and Ortiz (2008), and Duncan and Trejo (2018). This apparent lack of intergenerational progress in education after the second generation may be due in part to bias in who identifies as Hispanic (Duncan and Trejo 2011, 2017; Duncan et al. 2017). We discuss possible bias due to selective identification below.
} 
(Trejo 1997; Livingston and Kahn 2002; Fry and Lowell 2006; Blau and Kahn 2007; Duncan and Trejo 2018), few studies have examined differences across immigrant generations in employment, which is our focus here. There is also a large literature on intragenerational assimilation among Hispanic and other immigrants that examines whether their labor market outcomes catch up with those of U.S. natives as their duration of U.S. residence increases (e.g., Chiswick 1978; Borjas 1985). ${ }^{2}$ While understanding intragenerational assimilation is also important, it is not our focus here.

Specifically, this study examines the employment rates of Hispanic immigrants, the children of Hispanic immigrants (the second generation), and subsequent descendants of Hispanic immigrants (the third-plus generation). We present descriptive and multivariate analyses of employment rates for those groups absolutely, relative to each other, and relative to non-Hispanic white U.S. natives. We study the period 1996 to 2017, an era that encompasses the latter half of the Great Moderation and all of the Great Recession. The large swings in the business cycle during the second half of this period led to substantial changes in employment for all demographic groups. The first half of this period witnessed substantial growth in the number of Hispanic immigrants, and the size of the second and third-plus generations grew throughout the period as the children and later descendants of Hispanic immigrants reached working age.

Although studies of labor market outcomes often focus on earnings, employment is a key labor market outcome. Needs-based transfer programs increasingly emphasize employment, as exemplified by the growth in the Earned Income Tax Credit program, shrinkage in the Temporary Assistance for Needy Families program, and imposition of work requirements for food stamp and Medicaid recipients in some states. Working has therefore become even more

\footnotetext{
${ }^{2}$ See the National Academies of Sciences (2015) for a summary of the data and evidence on both intragenerational and intergenerational integration of immigrants.
} 
critical to most people's ability to make ends meet. In addition, differences in time spent employed over people's lifespan lead to gaps in accumulated work experience and job-related skills. Experience and skills gaps are likely to lead to differences in earnings. Income differentials then lead to disparities in savings and financial security during retirement. For immigrants, employment also facilitates integration into American society, which improves outcomes for future generations as well. Further, understanding the determinants of employment is a necessary precursor to understanding the determinants of earnings since earnings are conditional on employment.

The results here indicate substantial differences in Hispanics’ employment rates across immigrant generations. Hispanic immigrant men tend to have higher employment rates than second- and third-plus generation Hispanics do, while the opposite pattern holds among Hispanic women. Nonetheless, this pattern of intergenerational assimilation reverses between the second and the third-plus generations of Hispanic women. Overall, the results paint a discouraging picture of employment among Hispanics by the third generation and beyond that appears to be largely due to relatively low educational attainment. Selective ethnic attrition, the propensity for more successful Hispanics to stop identifying themselves as such, also may play a role in the observed employment decline between the second and third-plus generations.

\section{Background}

Traditional "straight line" assimilation theory predicts that each successive immigrant generation moves closer to the population average. Such convergence occurs because of intergenerational changes such as becoming fluent in English, moving out of ethnic enclaves, becoming more familiar with local institutions and customs, and intermarrying, among other reasons. 
Hispanics are a potential exception to this pattern of intergenerational assimilation for several reasons. First, discrimination and other adverse social and economic forces can result in segmented assimilation, when immigrants' descendants do not assimilate to overall population averages but rather to a lower average that prevails among non-whites or other disadvantaged populations (Gans 1992; Portes and Zhou 1993). Changes in underlying economic trends, such as rising income inequality, also may limit upward mobility for immigrants' descendants. Second, the first generation may even do better than later generations if the first generation is positively selected on observable or unobservable characteristics that are not fully passed down to later generations. Such downward assimilation may be particularly true for Hispanics when it comes to employment. Since many Hispanics immigrate in order to work in the United States, the first generation may have stronger labor force attachment than subsequent generations.

Differences in eligibility for safety net programs are another potential reason why intergenerational patterns in Hispanics' employment may be inconsistent with traditional models of immigrant assimilation. The large share of Hispanic immigrants who are unauthorized means that many of them do not qualify for social safety net programs like unemployment insurance and welfare. Limited access to the social safety net is likely to make Hispanic immigrants more willing than subsequent generations to take any job. In addition, selective return migration (e.g., by immigrants who cannot find a job) may cause the first generation to have a higher employment rate than subsequent generations, particularly in cross-sectional data.

Selective intermarriage and ethnic attrition also may create the perception that Hispanic immigrants’ outcomes do not improve across generations. If Hispanics with better socioeconomic outcomes are more likely to marry non-Hispanics, and there is some intergenerational transmission of socioeconomic outcomes, then more successful members of 
later generations may be less likely to identity as Hispanic. Even absent intermarriage, people who are more successful may be less likely to identify as racial/ethnic minorities. Consistent with this, intermarriage and ethnic attrition are positively related to education among Hispanics (Duncan and Trejo 2011; Duncan and Trejo 2017). ${ }^{3}$

Few studies have examined intergenerational differences among Hispanics in employment. Blau and Kahn (2007) show that Mexican immigrant men were more likely to be employed than U.S.-born white non-Hispanic men, controlling for age, during 1994 to 2003, while Mexican immigrant women are substantially less likely than their white counterparts to be employed. Second- and third-plus generation Mexican American men had the same employment rate after controlling for age, and both were less likely than their white counterparts to be employed. Third-plus generation women were more likely than second-generation women to be employed, and both generations were less likely than their white counterparts to be employed.

\section{Data and Methods}

This study primarily uses data from the Current Population Survey (CPS) for the period 1996 to 2017. The CPS is a large-scale survey of labor market outcomes conducted monthly among about 60,000 households in the United States. In addition to asking about labor market outcomes, the CPS asks about demographic characteristics, including Hispanic ethnicity, place of birth, and parents' place of birth. This enables us to determine whether someone who identifies as Hispanic is an immigrant or has at least one foreign-born parent.

Hispanics who are born abroad and not a U.S. citizen at birth are classified here as immigrants, or the first generation. The vast majority—about 88 percent—of Hispanic

\footnotetext{
${ }^{3}$ However, Jiménez, Park, and Pedroza (2017) note that intermarried Hispanics are more likely to report their children as Hispanic now than their parents' generation was 30 years ago.
} 
immigrants were born in Mexico, Central America, or the Caribbean. ${ }^{4}$ The second generation is Hispanics who are U.S. citizens at birth but have at least one parent who was born abroad. About 90 percent of second-generation Hispanics have at least one parent who was born in Mexico, Central America, or the Caribbean. ${ }^{5}$ The third-plus generation is Hispanics who are U.S. citizens at birth and whose parents were born in the United States or a U.S. territory. These Hispanics presumably have at least one grandparent, great-grandparent, or earlier forebearer who was born in a Spanish-speaking country, but the CPS does not indicate who and where. We are unable to distinguish between third and higher generations since the CPS does not ask about grandparents' birthplace. In our main analysis, we classify Hispanics who indicate they were born in Puerto Rico as third-plus generation Hispanics unless they have a parent who was born in a foreign country, in which case they are second-generation Hispanics. ${ }^{6}$

In addition to comparing Hispanics across immigrant generations, part of the analysis compares Hispanics to third-plus generation non-Hispanic whites (referred to here as "whites"). We also include third-plus generation non-Hispanic blacks (“blacks”) as a benchmark since they and Hispanics may face similar levels of discrimination and adverse labor market trends. Hispanics can be of any race, and the majority of them identify as white. We stratify our sample of Hispanics by race in part of the analysis below, but most of the analysis combines all Hispanics regardless of race. We limit the sample to people ages 25 to 59 in order to minimize differences across groups due to school enrollment or retirement. Because there are considerable

\footnotetext{
${ }^{4}$ The remainder are mostly from Spain or South America. The share of immigrants from Mexico, Central America, and the Caribbean who identify as Hispanic is also 88 percent. Most of the remainder of immigrants from those areas identify as non-Hispanic blacks and are from the Caribbean. We drop people with imputed Hispanic ethnicity or parental birthplace from our CPS sample.

${ }^{5}$ About 84 percent of the second generation with a parent born in Mexico, Central America, or the Caribbean identifies as Hispanic. As with the first generation, much of the remainder identify as non-Hispanic blacks and have at least one parent born in the Caribbean.

${ }^{6}$ Puerto Rico is a U.S. territory, and its residents are U.S. citizens at birth. About 30 percent of our sample of thirdplus generation Hispanics is Puerto Rican.
} 
differences in employment between Hispanic immigrant men and women, as discussed below, we conduct all of the analysis separately by sex. ${ }^{7}$

\section{Descriptive Statistics}

As Table 1 reports, Hispanic immigrants have the highest employment rate among the five groups of men we examine, followed by whites. The pattern is different among women: whites have the highest employment rate, while Hispanic immigrants have the lowest. This is consistent with the sizeable literature that documents strong labor force attachment among Hispanic immigrant men and relatively low employment among Hispanic immigrant women, although the latter group's labor force participation does tend to rise as their duration of U.S. residence increases (Blau and Kahn 2007).

The sample means suggest downward assimilation for Hispanic men across immigrant generations, at least as it pertains to employment. Second-generation Hispanic men are less likely to be working than the first generation, and third-plus generation Hispanics are less likely to be working than the second generation. Second- and third-plus Hispanic generation men are less likely than whites to be working, but more likely than blacks. For Hispanic women, the sample means suggest considerable upward assimilation in employment from the first to the second generation. The third-plus generation, however, has a lower employment rate than the second generation. The third-plus generation's employment rate is also lower than black women's rate, while all three generations of Hispanic women have lower employment rates than white women.

\footnotetext{
${ }^{7}$ We weight observations using their person weight. The results are robust to limiting the sample to housing units in their first of eight waves of participation in the CPS.
} 
Table 1 also shows sample means for key demographic characteristics included in the CPS. Several patterns are worth noting. Second-generation Hispanics are considerably younger than the other groups examined here. Hispanic immigrants also tend to be younger than whites and blacks but are older than second-generation Hispanics. Hispanic immigrants have much lower education levels than the other groups. Second- and third-plus generation Hispanics have considerably more education than Hispanic immigrants, but their education levels lag those of whites and blacks. Hispanic immigrants are the most likely to be married and have the most children, which likely contributes to the low employment rate among Hispanic immigrant women. Whites and blacks tend to live in states with better underlying economic conditions, as measured by the state unemployment rate, than Hispanics. Third-plus generation Hispanics tend to live in states with lower unemployment rates than first- or second-generation Hispanics.

These demographic differences likely contribute to the observed differences in employment rates across groups. In addition, the relationship between demographic characteristics and employment may differ across groups. We therefore turn to Blinder-Oaxaca decompositions to examine the relative roles of differences in observable characteristics and in returns to those characteristics in terms of employment.

\section{Methods}

The Blinder-Oaxaca decomposition involves first estimating linear probability regressions of employment separately by group. The estimated coefficients along with the sample means are then used to decompose the gap in the employment rate between the two groups into the portion due to differences in observable characteristics and the portion due to differences in coefficients, or 


$$
E m p_{A}-E m p_{B}=\left(\bar{X}_{A}-\bar{X}_{B}\right) \beta^{*}+\left[\bar{X}_{A}\left(\beta_{A}-\beta^{*}\right)+\bar{X}_{B}\left(\beta^{*}-\beta_{B}\right)\right],
$$

where $A$ and $B$ indicate the two demographic groups being compared. The first component of the decomposition, $\left(\bar{X}_{A}-\bar{X}_{B}\right) \beta^{*}$, is the difference in sample means evaluated at a "pooled," or average, coefficient across the two groups $\left(\beta^{*}\right)$. The second component of the decomposition, $\bar{X}_{A}\left(\beta_{A}-\beta^{*}\right)+\bar{X}_{B}\left(\beta^{*}-\beta_{B}\right)$, is the "unexplained" portion of the gap arising from differences in coefficients, or returns, evaluated at each group's respective sample means. The second component is often interpreted as the portion of the gap that is due to discrimination.

We focus on the role of four sets of variables in employment rate gaps across groups: age, education, family structure, and general economic conditions. In the linear probability regressions underlying equation (1), we measure age using indicator variables for single year of age rather than the broad age groups shown in Table $1 .{ }^{8}$ We measure education using indicator variables for whether someone has not completed high school, only completed high school, attended some college, or has at least a bachelor's degree. Our measures of family structure are marital status (married, divorced, widowed, separated, or never married), the number of children under age 6 at home, and the number of children age 6 and older at home. Our measures of general economic conditions are the state unemployment rate and time fixed effects (month by year). The former measures state-level economic conditions while the latter captures changes in national economic conditions. The time fixed effects also capture any other national-level changes that affect Hispanics and whites differently, such as changes in immigration policies. The estimates give the joint contribution of the differences in means or coefficients for each set

\footnotetext{
${ }^{8}$ When estimating the decompositions, we include the base category for each set of dummy variables and transform the coefficients into deviations from means so that the choice of the base category does not affect the results. Appendix Tables 1 and 2 show the estimated coefficients with a base category omitted for each set of indicator variables. The estimated coefficients of the age and year fixed effects are not included to conserve space but are available on request.
} 
of variables to the total employment rate gap between two groups; the tables also indicate whether the total employment gap and those joint contributions are statistically significant at conventional levels. ${ }^{9}$

As Table 1 shows, there are considerable differences in some of the sample means across groups. There are also considerable differences in some of the estimated coefficients from the linear probability regressions that underlie the Blinder-Oaxaca decompositions. Appendix Tables 1 and 2 report the estimated coefficients from the basic regressions for men and women, respectively. Hispanic immigrants have much smaller returns to education, or smaller penalties to low education levels and smaller rewards to high education levels, in terms of employment than the other groups examined here. The relationship between marital status and employment also tends to be different for Hispanic immigrants than for the other groups examined here. Indeed, many of the variables we include are less strongly related to employment for Hispanics immigrants than for other groups, as evidenced by the smaller coefficients for Hispanic immigrants in Appendix Tables 1 and 2. The estimated coefficients for second-generation Hispanics tend to be in between those for immigrants and the third-plus generation. This suggests intergenerational assimilation in the determinants of employment.

\section{Results}

Tables 2 and 3 present the main decomposition results for men and women, respectively. These decompositions all have whites as the benchmark. The first column in Table 2, for example, presents results for the employment gap between Hispanic immigrant men and white men. The raw employment gap is 0.018 , or Hispanic immigrant men are 1.8 percentage points more likely

\footnotetext{
${ }^{9}$ Standard errors for the contributions to the decompositions are available on request.
} 
than white men to be working. As the middle panel shows, that gap would be much larger absent the difference in education levels between the two groups: Hispanic immigrant men are 7.3 percentage points less likely than white men to be employed as a result of their lower education levels when evaluating the difference in education levels at the average relationship between education and employment for the two groups. Differences in economic conditions also narrow the employment gap between the two groups. Differences in age and family structure, in contrast, contribute to the employment rate gap between Hispanic immigrants and whites. The younger age distribution and higher marriage rate among Hispanic men boost their employment rate relative to white men.

Differences in the estimated relationship between education and employment also contribute to the employment gap between male Hispanic immigrants and whites, as the bottom panel in column 1 of Table 2 shows. Again, the gradient between education and employment is considerably flatter among Hispanic immigrants than among whites—-the employment penalty to not having completed high school is much smaller among Hispanic immigrants than among whites, and the employment gain to having attended or completed college is much smaller as well. Differences in the relationships between family structure variables and employment reduce the gap, in contrast. The difference in the constant, which captures unobserved factors, plays the biggest role in explaining why Hispanic immigrant men are more likely than white men to be employed. This is consistent with positive selection on unobservable characteristics among Hispanic immigrant men, as well as with undocumented status. Being undocumented, as well as arriving in the U.S. recently, means low eligibility for safety net programs, boosting labor force participation among Hispanic immigrant men, and possibly return migration by unemployed Hispanic immigrant men. 
As with Hispanic immigrants, education levels play an important role in the employment gap between second- and third-plus generation Hispanic and white men. Unlike Hispanic immigrant men, those groups are less likely than whites to be working. Lower levels of education can more than account for the employment gap between second-generation Hispanics and whites, while they can account for half of the employment gap for the third-plus generation. Their relative youth reduces the employment gaps between those two groups and whites, while differences in family structure-namely being more likely to be never married and less likely to have young children at home—contributes to the gaps. Differences in the estimated coefficients on the education variables make a small contribution to the gaps as well. Interestingly, while Hispanic immigrants have a smaller return to education in terms of employment than whites do, the opposite tend to hold for U.S.-born Hispanics—-the employment gains to attending college are typically higher for U.S.-born Hispanics than for whites (Appendix Tables 1 and 2).

Blacks serve as a comparison group of disadvantaged Americans. The magnitude of the employment gap between black and white men—14.2 percentage points—is considerably larger than between U.S.-born Hispanic and white men. Nonetheless, the pattern of the decomposition results tend to be similar for second- and third-plus generation Hispanic men and black men. There are two notable exceptions: the contributions of the estimated coefficients on education and economic conditions. The education coefficients play no role in explaining black-white employment differences, but that is because black men have a larger employment penalty to not completing high school and a larger employment premium to attending or completing college than white men, and those differences net to a zero contribution. With regard to economic conditions, black men's employment is considerably more cyclical than employment among 
whites or Hispanics, and this difference makes a major contribution to the employment gap between white and black men.

As with men, differences in education levels are an important contributor to employment gaps between Hispanic women and white women. As the first column of Table 3 reports, Hispanic immigrant women are more than 18 percentage points less likely than white women to be working, and differences in education levels can account for almost two-thirds of the gap. Differences in family structure and how family structure is related to employment are also important contributors to the employment gap between Hispanic immigrant women and whites: Hispanic immigrants have more young children at home, on average, and married Hispanic immigrant women are considerably less likely than never-married ones to be working, whereas employment rates do not differ significantly between married and never-married white women. ${ }^{10}$ Differences in economic conditions make a small contribution to the observed employment gap, whereas differences in age act to reduce the gap for all generations of Hispanic women relative to whites. As with Hispanic immigrant men, the flatter gradient between education and employment boosts the employment rate among Hispanic immigrant women relative to white women.

Second-generation Hispanic women are also less likely than white women to be working, but the gap narrows considerably to about 3 percentage points. Lower levels of education can fully account for the employment gap between female second-generation Hispanics and whites. Differences in family structure, economic conditions, and the relationship between education and employment also contribute to the employment gap between secondgeneration Hispanic women and whites. Differences in the relationship between economic

\footnotetext{
${ }^{10}$ Descriptive statistics for subsamples are available on request.
} 
conditions and employment act to raise employment among second-generation Hispanic women relative to whites, but this is largely offset by differences in the constant. Lower levels of education can explain almost three-fourths of the employment gap between third-plus generation Hispanic women and whites. Differences in family structure, namely having more young children, also contribute to the employment gap between third-plus generation Hispanic women and whites.

Black women fall in between second- and third-plus generation Hispanic women in terms of their employment gap relative to whites. As with Hispanic women, differences in education are a key factor in the employment gap between black and white women. Unlike white women, married black women are more likely than never-married ones to be working, a pattern that also holds among third-plus generation Hispanic women and that acts to reduce the employment gap for both groups.

\section{Differences by Hispanics' Race}

The above results combine all Hispanics regardless of race and compare them with non-Hispanic whites. But employment patterns may differ systematically by race, and intergenerational differences in the distribution of Hispanics by race may contribute to the patterns observed above. If assimilation is segmented for reasons related to race, employment rates of white Hispanics may become more similar to those of white non-Hispanics across generations, while employment rates of non-white Hispanics may become more similar to those of black nonHispanics. To examine this possibility, we separate Hispanics into those who are indicated as white only in the CPS, those who are mixed race or other race (anything other than white only or 
black only), and those who are black only. ${ }^{11}$ The top three rows of Table 4 show the employment gaps for those three racial groups relative to non-Hispanic whites by generation, while the bottom two rows show the employment gaps for mixed/other race and black Hispanics relative to black non-Hispanics.

The results indicate racial differences in the employment gaps, but the pattern of downward or segmented intergenerational assimilation is present for Hispanic men of all races and regardless of the reference group. Foreign-born Hispanic men who are white are more likely than white non-Hispanics to be working, whereas those who are black are less likely. For all three racial groups, second-generation Hispanic men are less likely than white non-Hispanics to be working, and the employment gap relative to non-Hispanic whites increases as we move from whites to mixed race to black Hispanics. The gaps widen for the third-plus generation, and this widening is more pronounced for mixed/other race and black Hispanics than for white Hispanics. Comparing mixed/other race and black Hispanic men with black non-Hispanic men (the bottom two rows of Table 4), Hispanics tend to initially have much higher employment rates than the latter, but the gap again narrows across generations.

In all three racial groups, foreign-born Hispanic women have lower employment rates than white or black non-Hispanic women. The gap goes away or turns positive, however, in the second generation. The jump in employment between first- and second-generation Hispanic women is followed by a drop between the second and third-plus generations. Comparing the coefficients within a given column reveals that within each generation, white Hispanic men are more likely than mixed/other race or black Hispanic men to be working. The same is true among

\footnotetext{
${ }^{11}$ White, black, and mixed/other race Hispanics make up 93, 3, and 4 percent, respectively, of Hispanic immigrants; 92, 3, and 5 percent of the Hispanic second generation, and 90, 5, and 5 percent of the Hispanic third-plus generation in our CPS sample.
} 
third-plus generation Hispanic women, but white foreign-born and second-generation Hispanic women are less likely to be employed than those who are mixed/other race or black.

\section{Differences by Country of Origin}

Differences by country of origin of immigrants themselves or their ancestors are also of potential interest. There may be differences by origin for several reasons, including differences in immigrant selectivity and motives for migration, in legal status, in the quality of education that immigrants received before migrating, and in cultural attitudes toward women working outside the home. Table 5 reports employment gaps relative to whites for the largest origin groups of Hispanics: Mexicans, Cubans, Dominicans, and Puerto Ricans. ${ }^{12}$

There is considerable diversity in employment gaps across Hispanics by origin. As the first column shows, among first-generation immigrants, only Mexican men are more likely than whites to be employed. Cuban- and Puerto-Rican born men are less likely than white men to be employed. Those two groups have relatively high eligibility rates for safety net programs since Puerto Ricans are U.S. citizens and almost all Cubans qualify for refugee status and legal permanent residence, after which they eventually are eligible to become naturalized U.S. citizens. Mexican immigrants, in contrast, are much more likely to be unauthorized and hence ineligible for government assistance programs. As the fourth column shows, all groups of firstgeneration (immigrant) Hispanic women are less likely than whites to be employed, but there are

\footnotetext{
${ }^{12}$ Until now, Puerto Ricans have been included in the third-plus generation since they are US citizens. In Table 5, "immigrants" from Puerto Rico is all Hispanics living in the U.S. who were born in Puerto Rico; the second generation is Hispanics who have at least one parent born in Puerto Rico; and the third-plus generation is Hispanics born in the U.S. whose ethnicity is reported as Puerto Rican with parents also born in the U.S. Public school education in Puerto Rico is conducted in Spanish, potentially making Puerto Ricans quite different from other U.S.born Hispanics. The results for the third-plus generation in Tables 2 and 3 are robust to dropping Puerto Ricans from the sample, although the employment gaps relative to whites are about 2 percentage points smaller. The third-plus generation still has a significantly lower employment rate than the second generation when Puerto Ricans are dropped.
} 
considerable differences in the magnitude of the employment gap. As the fifth column shows, second-generation Cuban American women are actually more likely than white women to be employed. The pattern of downward assimilation suggested by larger employment gaps between third-plus generation Hispanics and whites than between second-generation Hispanics and whites occurs among Mexican American men and among Cuban American and Dominican American men and women.

In decomposition results not show here, differences in education levels and in family structure contribute to lower employment rates among most country of origin groups of Hispanics relative to whites. ${ }^{13}$ The one notable exception is second-generation Cuban Americans, whose education levels boost their employment rates relative to whites' rates. Differences in the age structure boost employment rates among most origin groups of Hispanics relative to whites. There is no clear pattern in the contributions of differences in the estimated coefficients.

\section{Differences by Naturalized U.S. Citizenship}

We now turn from comparisons between Hispanics and whites to comparisons between groups of Hispanics. We first compare Hispanic immigrants who are naturalized U.S. citizens with those who are not. Many Hispanic immigrants who are not naturalized citizens are unauthorized immigrants, but certainly not all. Naturalization rates are particularly low among eligible Mexican immigrants (Gonzalez-Barrera 2017). Naturalized immigrants may be more assimilated since they have usually been in the United States longer than other immigrants and because immigrants must take the citizenship test in English unless they are elderly. Given that

\footnotetext{
${ }^{13}$ All results discussed but not shown are available on request.
} 
Hispanic immigrant men are more likely than whites to be employed, assimilation may mean a lower likelihood of employment. In addition, the near-universal labor force participation among unauthorized immigrant men may cause the employment rate to be higher among nonnaturalized men than among naturalized men. The opposite is likely to be the case among women. Unauthorized immigrant women tend to have lower labor force participation and employment rates than legal immigrant women (Orrenius and Zavodny 2015).

The results only partly bear out these predictions. As column 1 of Table 6 indicates, there is no significant difference in employment between naturalized and non-naturalized Hispanic immigrant men. However, Hispanic immigrant women who are naturalized citizens are much more likely than non-naturalized citizens to be employed (column 2). The gap is driven by higher education levels, fewer children at home, and differences in how family structure is related to employment.

\section{Differences by Age at Arrival}

Immigrants who arrived as children are typically more assimilated than those who arrived as adults. Childhood arrivals are more likely to attend at least some school in the United States, which typically increases their English fluency and their familiarity with U.S. culture and institutions. Because their outcomes often fall in between those of immigrants who arrived as adults and the second generation, childhood arrivals are sometimes called the 1.5 generation. Given the patterns among Hispanic immigrants as a whole relative to whites, male childhood arrivals may be less likely to be working than male adult arrivals, while the opposite may be true among females. 
Columns 3 and 4 of Table 6 indicate this is indeed the case, especially among women. Male Hispanic immigrants who arrived at age 15 or younger are about 1 percentage point less likely to be working than those who arrived at age 16 or older. Females who arrived at age 15 or younger are more than 10 percentage points more likely to be working than those who arrived at age 16 or older. Childhood arrivals have more education, on average, which boosts their employment relative to adult arrivals. Differences in the relationship between family structure and employment also act to boost employment among child arrivals relative to adult arrivals, particularly for women. However, differences in the relationship between education and employment act to reduce the employment rate among childhood arrivals relative to adult arrivals. Other, unobservable factors drive the lower employment rate among male childhood arrivals relative to adult arrivals. This may reflect the fact that most male adult arrivals are labor migrants, whereas childhood arrivals likely migrated for a wider variety of reasons.

\section{Differences by Number of Foreign-born Parents}

Having one versus two foreign-born parents may affect the extent of assimilation among second-generation immigrants. Second-generation Hispanics who have only one foreign-born parent may be more assimilated than those with two foreign-born parents. Given the patterns among Hispanic immigrants as a whole, this would predict that second-generation Hispanic men with one foreign-born parent have a lower employment rate than those with two foreign-born parents, while the opposite should hold among women.

The results bear out this prediction for men but not for women. Columns 5 and 6 of Table 6 show the decomposition of the employment gap between second-generation Hispanics with one versus two foreign-born parents. As predicted, Hispanic men with only one foreign-born 
parent are less likely than those with two foreign-born parents to be working. This result is consistent with the downward assimilation suggested by the overall results for men in Table 2 . The gap is mainly due to differences in unobservable factors captured by the constant. Hispanic women with only one foreign-born parent are also less likely to be working that those with two foreign-born parents. This result is surprising since we would expect upward assimilation in employment among women. Differences in the age and education distributions contribute to the employment gap for women.

\section{Employment Gaps across Hispanic Immigrant Generation Cohorts}

Generational comparisons in cross-sectional data like those presented above may be misleading because they do not necessarily match parents and grandparents with their descendants (Smith 2003, 2006; Duncan et al. 2017). Our use of a fairly long time period, 19962017, and a wide age range, 25-59, exacerbates this concern. Although we cannot match parents with their adult children in the CPS unless they live in the same household, we can construct synthetic generations comprised of likely parents and their children by narrowing the time period and age range we use. ${ }^{14}$ Specifically, we examine two shorter time periods, 1996-1997 and 20162017, and a smaller ten-year age group, age 25-34. Doing so enables us to compare a parents’ generation—immigrant or second-generation Hispanics who are ages 25-34 in 1996-1997—with their children's generation—second- or third-plus generation Hispanics who are ages 25-34 in 2016-2017. Table 7 reports the employment rates for these groups and time periods.

The patterns of the employment rates across immigrant generation cohorts over time are similar to the earlier cross-sectional results. For Hispanic men, employment declines across

\footnotetext{
${ }^{14}$ Studies using this immigration generation cohort approach (also sometimes termed "lagged birth cohorts") include Farley and Alba (2002), Smith (2003), and Park and Myers (2010).
} 
immigrant generation cohorts. The employment rate among Hispanic immigrant men in 19961997 was 89 percent, versus 85 percent among second-generation Hispanic men in 2016-2017. The drop between the second- and third-plus generations is even larger, from 88 percent to 81 percent. For Hispanic women, employment is substantially lower among immigrants in 19961997 than among the second generation in 2017-2017, at 49 percent versus 71 percent. Employment is higher among the second generation than among the third-plus generation, however, at 72 percent versus 69 percent. This pattern is consistent with downward intergenerational assimilation among men, and upward then downward intergenerational assimilation among women.

Table 8 presents results for Blinder-Oaxaca decompositions of the employment gaps across immigrant generation cohorts over time. ${ }^{15}$ The results again point to differences in mean education levels and in the relationship between education and employment as major determinants of the employment gap across Hispanic immigrant generations. In all four comparisons, the earlier generation has less education, on average, which acts to reduce employment among parents relative to their children. Differences in the relationship between education and employment reduce employment among children relative to their parents, in contrast, for three of the groups. Differences in family structure reduce employment among men relative to their fathers' generation but raise employment among women relative to their mothers' generation. Differences in the relationship between economic conditions and employment drive the lower employment rate among the third-plus generation in 2016-2017 than among their parents’ generation in 1996-1997.

\footnotetext{
15 The decompositions include only the state unemployment rate as a measure of economic conditions. The time fixed effects are not included since the two generations are observed at different points in time.
} 
In results not shown here, intergenerational gaps in employment are smaller if we instead examine ages 35-44 or 45-54. The employment gap is not statistically significant between firstand second-generation men and between second- and third-plus generation women if we examine those age groups. There is still a significant drop in employment from second- to thirdplus generation men and a significant increase in employment from first- to second-generation women. There are several potential reasons why the pattern of downward assimilation is more pronounced at younger ages than at older ages. ${ }^{16}$ Employment of younger adults may have fallen over time, perhaps due to structural changes in the economy or to increased enrollment in higher education while people are in the their late 20s and early 30s. Among immigrant men, employment may fall with age due to intragenerational assimilation—recently arrived Hispanic immigrant men are more likely to work than those who arrived longer ago, whereas the opposite holds among women. Older Hispanics immigrants have been in the U.S. longer, all else equal, and therefore more closely resemble the second generation in terms of employment rates. Alternatively, younger second- and third-generation Hispanics may differ in observable or unobservable ways from their older counterparts. For example, younger second-generation Hispanics are more likely than older ones to have two foreign-born parents (Perlmann 2005). Whether the intergenerational gap persists or ameliorates as young second-generation Hispanics move through the lifecycle is a key question.

\footnotetext{
${ }^{16}$ In addition to the potential reasons offered here, second-generation Hispanics are concentrated in the 25-34 age range, which contributes to the decline in statistical significance when making intergenerational comparisons with older age groups.
} 


\section{Disentangling the Third-Plus Generation and Ethnic Attrition}

The above results for the third-plus generation combine Hispanics with at least one foreign-born grandparent with Hispanics whose families have been in the United States for a century or more. The CPS does not allow us to distinguish between the third and higher generations. To distinguish between the third and fourth-plus generations we turn to the National Longitudinal Survey of Youth 1997 (NLSY97). Like the CPS, the NLSY97 asked participants' Hispanic ethnicity and the birthplace of their parents, but it also has questions about the birthplace of grandparents. ${ }^{17}$ The NLSY97 is a panel study of about 9000 participants who were ages 12 to 17 when first interviewed in 1997. The study included an oversample of Hispanics (and blacks). All immigrants in the NLSY97 are childhood arrivals since the sample is not replenished over time, and a smaller share of them may be unauthorized than among the CPS sample. Hispanic immigrants in the NLSY97 therefore may be more assimilated than a representative sample of all Hispanic immigrants. We use data from round 15, which occurred in 2011 for most participants. Respondents were ages 26 to 31 at that time. ${ }^{18}$ We use a cross section from the NLSY instead of exploiting its panel nature since we focus on differences across immigrant generations at a given point in time instead of changes over time as a given cohort in each immigrant generation ages. With just one cohort to observe, we would be combining aging, assimilation, and time effects.

Table 9 reports the employment rate among NLSY97 participants by immigrant generation. ${ }^{19}$ A number of patterns are similar in the NLSY97 and the CPS data. Male Hispanic

\footnotetext{
${ }^{17}$ We thank Brian Duncan for sharing his program for identifying Hispanic immigrant generations in the NLSY97.

${ }^{18}$ If we limit our CPS sample to people ages 26 to 31 and the year 2011, we obtain results generally similar to those shown in Tables 2 and 3 . The only notable difference is that the employment gap between second-generation Hispanics and whites is not statistically significant for men or women.

${ }^{19}$ As with our CPS sample, we limit our NLSY97 samples of non-Hispanic whites and blacks to those who are U.S.born children of U.S.-born parents (third-plus generation). The decompositions use only the state unemployment rate as a measure of economic conditions since there is little time variation in the sample.
} 
immigrants have the highest employment rate, and all other immigrant generations of Hispanic men are less likely than whites to be employed. Female Hispanic immigrants have the lowest employment rate, and the employment rate is substantially higher among second-generation Hispanic women than among Hispanic immigrant women. All immigrant generations of Hispanic women are less likely than whites to be employed.

The NLSY97 data reveal a substantial difference between the third and the fourth-plus Hispanic immigrant generations. For both men and women, the third generation is more likely than the second generation to be working. Meanwhile, the fourth-plus generation is substantially less likely than the third and second generations to be working. This suggests that the fourth-plus generation drives the drop in employment between the second and third-plus generations observed in the CPS data. However, we caution that the NLSY97 Hispanic generations are small sample sizes and may not be representative of the broader Hispanic population: they are a particular age and birth cohort, and they were willing to participate in a very detailed survey (and remained in it for a long time, since we examine the $15^{\text {th }}$ wave of the survey).

Tables 10 and 11 present Blinder-Oaxaca decomposition results for Hispanic and black men and women in the NLSY97, respectively, relative to whites. As in the CPS data, the results indicate that lower average education levels reduce employment among Hispanics of every immigrant generation relative to whites. The same is true for blacks relative to whites. The relationship between education and employment widens the gap between second- and thirdgeneration Hispanic women and whites, while it narrows the gap for third-generation Hispanic men.

The finding that fourth-plus generation Hispanics appear to be more disadvantaged than other Hispanics is consistent with previous research showing a similar pattern for educational 
attainment (Alba et al. 2011; Bean et al. 2015; Duncan et al. 2017). As Duncan et al. (2017) note, fourth-plus generation Hispanics are the descendants of ancestors who often faced severe, institutionalized discrimination in the United States. In southwestern parts of the U.S., Hispanics experienced levels of discrimination akin to those experienced by blacks in the South before the Civil Rights movement (Perlmann 2005). ${ }^{20}$ Another factor that may explain why fourth-plus generation Hispanics appear to fare particularly poorly in terms of education and employment is selective ethnic attrition. Relatively few people with grandparents or higher who immigrated to the United States from a Spanish-speaking country may identify as Hispanic, and those who do may differ systematically from those who do not. If people who are identified as Hispanic in the surveys are less likely to be employed than people who also have Hispanic roots but are not identified as Hispanic, selective ethnic attrition may contribute to our findings.

The CPS and NLSY97 data allow us to examine, albeit only partially, the extent of ethnic attrition in our sample. There is little evidence of ethnic attrition through the second generation in the CPS data and through the third generation in the NLSY97 data. Almost all immigrants from Mexico and Central America, which account for the vast majority of Hispanic immigrants in the United States, are identified as Hispanic by the CPS Hispanic ethnicity question. Further, over 90 percent of prime-age U.S.-born adults with at least one parent born in Mexico or Central America—second-generation immigrants—are identified as Hispanic in our CPS sample. In our NLSY97 sample, all of the first- and second-generation immigrants with roots in Mexico or Central America are identified as Hispanic by the survey’s Hispanic ethnicity variables. Almost 94 percent of people with a grandparent born in Mexico or Central America —-third-generation

\footnotetext{
${ }^{20}$ About 40 percent of fourth-plus generation Hispanics in our NLSY97 sample appear to be Mexican American, and 15 percent Puerto Rican.
} 
immigrants—are identified as Hispanic. ${ }^{21}$ We are unable to estimate the extent of ethnic attrition in the fourth-plus generation in the NLSY97 and in the third-plus generation in the CPS. Unfortunately, those are the generations where selective ethnic attrition may be the most prevalent. It therefore is an open question whether the apparent downward intergenerational assimilation in employment among Hispanics is due to selective ethnic attrition, particularly among the third-plus or fourth-plus generation.

\section{Conclusion and Policy Implications}

Researchers and policymakers often view U.S. Hispanics as a single, uniform group. Doing so not only combines Hispanics from different origin areas but also combines immigrants and their U.S.-born descendants. This study indicates that there are several notable differences in employment across Hispanic immigrant generations: First-generation Hispanic men are more likely than second- and third-plus generation men to be employed. There is a large jump in employment from first- to second-generation Hispanic women, whereas third-plus generation women are less likely than second-generation women to be employed. Taken together, the results point to segmented assimilation among Hispanics, particularly for Hispanic men. Although there are differences in employment rates by Hispanics' race, a pattern of downward movement across generations prevails for white and non-white Hispanics alike, with the exception of first- to second-generation women. Selective ethnic attrition beyond the third generation may contribute to the patterns observed here. But even if selective ethnic attrition does underlie the results, the

\footnotetext{
${ }^{21}$ For comparison, other research indicates that 97 percent of immigrant adults from Latin America or Spain identify themselves as Hispanic, compared with 92 percent of the second generation, 77 percent of the third generation, and only one-half of the fourth-plus generation (Lopez, Gonzalez-Barrera, and López 2017).
} 
fact that U.S. natives who identify as Hispanic have lower employment rates than people who identify as non-Hispanic whites is a cause for concern and warrants further study.

This study offers a detailed examination of intergenerational differences in Hispanics’ employment. It raises a number of areas for further research, including in-depth analysis of the causes of the patterns revealed here. Understanding why U.S.-born Hispanics' education levels lag behind those of non-Hispanic whites is particularly important. Although the share of Hispanic young adults who have not completed high school has fallen considerably over time, it still remains twice that among non-Hispanic whites and above that of non-Hispanic blacks as well (Gramlich 2017). Examining intragenerational changes as cohorts age and as the U.S. economy evolves—a topic we do not examine here—is also worthy of attention. The discouraging picture painted by the data used here may moderate or even disappear as today's large young cohorts of second- and third-generation Hispanics age.

The high employment rate among male Hispanic immigrants suggests that immigration policy, perhaps in conjunction with other policies that limit access to the safety net, attracts Hispanic immigrant men who work. But low employment rates among second and especially third-plus generation Hispanic men and women relative to non-Hispanic whites point to the importance of finding policies that can help remediate the disadvantages Hispanic immigrants' descendants may face. Increasing educational attainment, particularly high school graduation rates, and school quality is a key area. Doing so will become increasingly important in the United States since the size and share of the native-born Hispanic population are projected to continue to grow in the coming decades. 


\section{References}

Alba, Richard, Dalia Abdel-Hady, Tariqul Islam, and Karen Marotz (2011). "Downward Assimilation and Mexican Americans: An Examination of Intergenerational Advance and Stagnation in Educational Attainment.” Pp. 95-109 in The Next Generation: Immigrant Youth in a Comparative Perspective, ed. Richard Richard and Mary C. Waters. New York: NYU Press. https://doi.org/10.18574/nyu/9780814707425.003.0005

Bean, Frank D., Susan K. Brown, and James D. Bachmeier (2015). Parents without Papers: The Progress and Pitfalls of Mexican American Integration. Washington, DC: Russell Sage Foundation.

Blau, Francine C., and Lawrence M. Kahn (2007). "Gender and Assimilation among Mexican Americans.” Pp. 57-106 in Mexican Immigration to the United States, ed. George J. Borjas. Chicago: University of Chicago Press. https://doi.org/10.7208/chicago/9780226066684.003.0003

Borjas, George J. (1985). “Assimilation, Changes in Cohort Quality, and the Earnings of Immigrants.” Journal of Labor Economics 3(4): 463-489. https://doi.org/10.1086/298065

Chiswick, Barry R. (1978). "The Effect of Americanization on the Earnings of Foreign-Born Men.” Journal of Political Economy 86(5): 897-921. https://doi.org/10.1086/260717

Duncan, Brian, and Stephen J. Trejo (2011). “Tracking Intergenerational Progress for Immigrant Groups: The Problem of Ethnic Attrition.” American Economic Review 101(3): 603-608. https://doi.org/10.1257/aer.101.3.603

Duncan, Brian, and Trejo, Stephen J. (2017). “The Complexity of Immigrant Generations: Implications for Assessing the Socioeconomic Integration of Hispanics and Asians.” Industrial and Labor Relations Review 70(5), pp. 1146-75. https://doi.org/10.1177/0019793916679613

Duncan, Brian, and Stephen J. Trejo. (2018). "Socioeconomic Integration of U.S. Immigrant Groups over the Long Term: The Second Generation and Beyond.” NBER Working Paper No. 24394. https://doi.org/10.3386/w24394

Duncan, Brian, Jeffrey Grogger, Ana Sofia Leon, and Stephen J. Trejo (2017). "New Evidence of Generational Progress for Mexican Americans.” NBER Working Paper 24067. https://doi.org/10.3386/w24067

Duncan, Brian, V. Joseph Hotz, and Stephen J. Trejo (2006). "Hispanics in the U.S. Labor Market.” Pp. 228-290 in Hispanics and the Future of America, ed. Marta Tienda and Faith Mitchell. Washington, DC: The National Academies Press. https://doi.org/10.17226/11539

Farley, Reynolds, and Richard Alba (2002). "The New Second Generation in the United States.” International Migration Review 36(3): 669-701.

https://doi.org/10.1111/j.1747-7379.2002.tb00100.x 
Fry, Richard, and B. Lindsay Lowell (2006). "The Wage Structure of Latino-Origin Groups across Generations.” Industrial Relations 45(2): 147-168.

https://doi.org/10.1111/j.1468-232x.2006.00421.x

Gans, Herbert J. (1992). "Second Generation Decline: Scenarios for the Economic and Ethnic Futures of the Post-1965 American Immigrants.” Ethnic and Racial Studies 15(2): 173-192. https://doi.org/10.1080/01419870.1992.9993740

Gonzalez-Barrera, Ana (2017). "Mexican Lawful Immigrants Among the Least Likely to Become U.S. Citizens.” Washington, DC: Pew Research Center.

Gramlich, John (2017). "Hispanics Dropout Rate Hits New Low, College Enrollment at New High.” Washington, DC: Pew Research Center.

Grogger, Jeffrey, and Stephen J. Trejo (2002). "Falling Behind or Moving Up? The Intergenerational Progress of Mexican Americans." San Francisco: Public Policy Institute of California.

Jiménez, Tomás R., Julie Park, and Juan Pedroza (2017). “The New Third Generation: Post-1965 Immigration and the Next Chapter in the Long Story of Assimilation.” International Migration Review forthcoming. https://doi.org/10.1111/imre.12343

Livingston, Gretchen, and Joan R. Kahn (2002). “An American Dream Unfulfilled: The Limited Mobility of Mexican Americans.” Social Science Quarterly 83(4): 1003-1012. https://doi.org/10.1111/1540-6237.00129

Lopez, Mark H., Ana Gonzalez-Barrera, and Gustavo López (2017). "Hispanic Identity Fades Across Generations as Immigrant Connections Fall Away.” Washington, DC: Pew Research Center.

National Academies of Sciences (2015). The Integration of Immigrants into American Society. Mary C. Waters and Marisa G. Pineau, eds. Washington, DC: The National Academies Press. https://doi.org/10.17226/21746

Orrenius, Pia M., and Madeline Zavodny (2015). "The Impact of Temporary Protected Status on Immigrants’ Labor Market Outcomes.” American Economic Review Papers \& Proceedings 105(3): 576-580. https://doi.org/10.1257/aer.p20151109

Park, Julie, and Dowell Myers (2010). "Intergenerational Mobility in the Post-1965 Immigration Era: Estimates by an Immigrant Generation Cohort Method.” Demography 47(2): 369-392. https://doi.org/10.1353/dem.0.0105

Perlmann, Joel (2005). Italians Then, Mexicans Now: Immigrant Origins and Second-Generation Progress, 1890 to 2000. New York: Russell Sage Foundation. 
Portes, Alejandro, and Min Zhou (1993). "The New Second Generation: Segmented Assimilation and Its Variants." Annals of the American Academy of Political and Social Science 530: 74-96. https://doi.org/10.1177/0002716293530001006

Smith, James P. (2003). “Assimilation across the Latino Generations.” American Economic Review 93 (2): 315-319. https://doi.org/10.1257/000282803321947263

Smith, James P. (2006). “Immigrants and the Labor Market.” Journal of Labor Economics 24: 203-233. https://doi.org/10.1086/499971

Telles, Edward E., and Vilma Ortiz (2008). Generations of Exclusion: Mexican Americans, Assimilation, and Race. New York: Russell Sage Foundation.

Trejo, Stephen J. (1997). “Why Do Mexican Americans Earn Low Wages?” Journal of Political Economy 105(6): 1235-1268. https://doi.org/10.1086/516391

Trejo, Stephen J. (2003). "Intergenerational Progress of Mexican-Origin Workers in the U.S. Labor Market.” Journal of Human Resources 38(3): 468-489.

https://doi.org/10.3368/jhr.xxxviii.3.467 
Table 1

Descriptive Statistics of CPS Samples, by Sex, Race/Ethnicity and Immigrant Generation

\begin{tabular}{|c|c|c|c|c|c|}
\hline & \multicolumn{3}{|c|}{ Hispanic } & \multicolumn{2}{|c|}{ Non-Hispanic } \\
\hline & Immigrants & $2 \stackrel{\text { nd }}{2}$ gen. & $3^{\text {rd }}+$ gen. & Blacks & Whites \\
\hline \multicolumn{6}{|l|}{ Men: } \\
\hline Employed & 0.880 & 0.841 & 0.795 & 0.721 & 0.862 \\
\hline Age $25-34$ & 0.368 & 0.501 & 0.359 & 0.303 & 0.261 \\
\hline Age 35-49 & 0.466 & 0.370 & 0.435 & 0.451 & 0.451 \\
\hline Less than HS diploma & 0.505 & 0.167 & 0.181 & 0.134 & 0.071 \\
\hline HS diploma & 0.271 & 0.324 & 0.374 & 0.406 & 0.319 \\
\hline Some college & 0.123 & 0.307 & 0.285 & 0.291 & 0.275 \\
\hline College graduate & 0.100 & 0.202 & 0.160 & 0.169 & 0.335 \\
\hline Married & 0.700 & 0.542 & 0.561 & 0.459 & 0.656 \\
\hline Divorced & 0.049 & 0.076 & 0.110 & 0.115 & 0.115 \\
\hline Widowed & 0.005 & 0.004 & 0.006 & 0.011 & 0.007 \\
\hline Separated & 0.030 & 0.028 & 0.031 & 0.046 & 0.017 \\
\hline Number of kids age $6+$ at home & 1.107 & 0.765 & 0.842 & 0.658 & 0.745 \\
\hline Number of kids under 6 at home & 0.304 & 0.281 & 0.228 & 0.154 & 0.192 \\
\hline State unemployment rate & 6.339 & 6.439 & 6.071 & 5.976 & 5.798 \\
\hline Number of observations & 514,153 & 120,099 & 250,462 & 572,791 & $5,168,097$ \\
\hline \multicolumn{6}{|l|}{ Women: } \\
\hline Employed & 0.556 & 0.707 & 0.669 & 0.692 & 0.739 \\
\hline Age $25-34$ & 0.332 & 0.491 & 0.351 & 0.302 & 0.260 \\
\hline Age 35-49 & 0.476 & 0.370 & 0.311 & 0.452 & 0.449 \\
\hline Less than HS diploma & 0.470 & 0.151 & 0.181 & 0.120 & 0.056 \\
\hline HS diploma & 0.267 & 0.277 & 0.335 & 0.341 & 0.293 \\
\hline Some college & 0.145 & 0.333 & 0.311 & 0.331 & 0.306 \\
\hline College graduate & 0.118 & 0.238 & 0.173 & 0.207 & 0.345 \\
\hline Married & 0.680 & 0.542 & 0.529 & 0.349 & 0.670 \\
\hline Divorced & 0.084 & 0.115 & 0.148 & 0.156 & 0.141 \\
\hline Widowed & 0.020 & 0.017 & 0.023 & 0.035 & 0.022 \\
\hline Separated & 0.059 & 0.051 & 0.057 & 0.068 & 0.023 \\
\hline Number of kids age $6+$ at home & 1.410 & 1.039 & 1.128 & 0.988 & 0.851 \\
\hline Number of kids under 6 at home & 0.306 & 0.314 & 0.235 & 0.179 & 0.196 \\
\hline State unemployment rate & 6.341 & 6.380 & 6.057 & 5.982 & 5.798 \\
\hline Number of observations & 499,809 & 133,476 & 295,923 & 783,670 & $5,413,675$ \\
\hline
\end{tabular}

Note: Shown are weighted means for people ages 25-59 in the 1996-2017 CPS. Hispanics can be of any race. Non-Hispanic whites and blacks are $3^{\text {rd }}+$ generation. Observations are weighted using the final person weights. 
Table 2

Decomposition Results for Male Employment Gap Relative to Non-Hispanic Whites

\begin{tabular}{|c|c|c|c|c|}
\hline & $\begin{array}{c}\text { Hispanic } \\
\text { Immigrants }\end{array}$ & $\begin{array}{l}\text { Hispanic } \\
2^{\frac{\text { nd }}{}} \text { gen. }\end{array}$ & $\begin{array}{l}\text { Hispanic } \\
3^{\text {rd }}+\text { gen. }\end{array}$ & $\begin{array}{c}\text { Non-Hispanic } \\
\text { Blacks }\end{array}$ \\
\hline Employment gap & $0.018 * * *$ & $-0.021 * * *$ & $-0.067 * * *$ & $-0.142 * * *$ \\
\hline
\end{tabular}

Due to differences in means:

Age

Education

Marital status and kids

Economic conditions

$\begin{array}{rlll}0.015 * * * & 0.022 * * * & 0.011 * * * & 0.005 * * * \\ -0.073 * * * & -0.026 * * * & -0.033 * * * & -0.026 * * * \\ 0.009 * * * & -0.014 * * * & -0.009 * * * & -0.025 * * * \\ -0.008 * * * & -0.011 * * & -0.005 * * & -0.003 * *\end{array}$

Due to differences in coefficients:

\begin{tabular}{lllll} 
Age & -0.0001 & 0.001 & $0.003^{* *}$ & $0.001^{* * *}$ \\
Education & $0.027^{* * *}$ & $-0.005^{* * *}$ & $-0.004^{* * *}$ & 0.0003 \\
Marital status and kids & $-0.036^{* * *}$ & -0.007 & -0.001 & -0.003 \\
Economic conditions & 0.010 & $0.029^{* *}$ & 0.021 & $-0.057^{*}$ \\
Constant & $0.074^{* * *}$ & -0.010 & -0.050 & -0.033 \\
\hline
\end{tabular}

$* \mathrm{p}<0.1 ; * * \mathrm{p}<0.05 ; * * * \mathrm{p}<0.01$

Note: Shown are results from Oaxaca decompositions of the employment gap between the indicated group and $3^{\text {rd }}+$ generation non-Hispanic whites (see text for details). 
Table 3

Decomposition Results for Female Employment Gap Relative to Non-Hispanic Whites

\begin{tabular}{lcccc}
\hline & $\begin{array}{c}\text { Hispanic } \\
\text { Immigrants }\end{array}$ & $\begin{array}{c}\text { Hispanic } \\
2^{\text {nd }} \text { gen. }\end{array}$ & \begin{tabular}{l} 
Hispanic \\
$3^{\text {rd }}$ \\
\hline Employment gap
\end{tabular} & $\begin{array}{c}\text { Non-Hispanic } \\
\text { Blacks }\end{array}$ \\
\hline$-0.183^{*} * *$ & $-0.032 * * *$ & $-0.070 * * *$ & $-0.047 * * *$
\end{tabular}

Due to differences in means:

Age

$\begin{array}{llll}0.009 * * * & 0.016 * * * & 0.009 * * * & 0.005 * * * \\ -0.119 * * * & -0.035^{* * *} & -0.052 * * * & -0.033^{* * *} \\ -0.026 * * * & -0.016^{* * *} & -0.010^{* * *} & -0.002 \\ -0.009 * * & -0.011^{* *} & -0.005 & -0.003 * *\end{array}$

Due to differences in coefficients:

\begin{tabular}{lcccc} 
Age & $-0.002^{* *}$ & -0.003 & 0.002 & 0.0004 \\
Education & $0.013^{*}$ & $-0.005^{* * *}$ & $-0.002^{* *}$ & $-0.003^{* *}$ \\
Marital status and kids & $-0.070^{* * *}$ & 0.003 & $0.013^{*}$ & $0.038^{* * *}$ \\
Economic conditions & 0.064 & $0.080^{* * *}$ & 0.042 & -0.008 \\
Constant & -0.042 & $-0.060^{* *}$ & -0.067 & -0.071 \\
\hline
\end{tabular}

$* \mathrm{p}<0.1 ; * * \mathrm{p}<0.05 ; * * * \mathrm{p}<0.01$

Note: Shown are results from Oaxaca decompositions of the employment gap between the indicated group and $3^{\text {rd }}+$ generation non-Hispanic whites (see text for details). 
Table 4

Employment Gaps by Race

\begin{tabular}{|c|c|c|c|c|c|c|}
\hline & \multicolumn{3}{|c|}{ Men } & \multicolumn{3}{|c|}{ Women } \\
\hline & Immigrants & $2^{\text {nd }}$ gen. & $3^{\text {rd }}+$ gen. & Immigrants & $2^{\text {nd }}$ gen. & $3^{\text {rd }}+$ gen. \\
\hline White Hispanics, white non-Hispanics & $0.019 * * *$ & $-0.020 * * *$ & $-0.062 * * *$ & $-0.186 * * *$ & $-0.035 * * *$ & $-0.068 * * *$ \\
\hline Mixed/other race Hispanics, white non-Hispanics & 0.015 & $-0.035 * *$ & $-0.091 * * *$ & $-0.164 * * *$ & -0.011 & $-0.082 * * *$ \\
\hline Black Hispanics, white non-Hispanics & $-0.024 *$ & $-0.063^{* *}$ & $-0.155 * * *$ & $-0.115 * * *$ & 0.015 & $-0.103 * * *$ \\
\hline Mixed/other race Hispanics, black non-Hispanics & $0.157 * * *$ & $0.107 * * *$ & $0.050 * * *$ & $-0.117 * * *$ & $0.036 * *$ & $-0.035 * * *$ \\
\hline Black Hispanics, black non-Hispanics & $0.118 * * *$ & $0.079 * * *$ & -0.013 & $-0.068 * * *$ & $0.062 * *$ & $-0.056 * *$ \\
\hline
\end{tabular}

$* \mathrm{p}<0.1 ; * * \mathrm{p}<0.05 ; * * * \mathrm{p}<0.01$

Note: Shown are employment gaps between the indicated group of Hispanics and $3^{\text {rd }}+$ generation non-Hispanic whites or blacks.

Mixed/other race Hispanics is Hispanics whose race is identified as any category other than white only or black only, and black

Hispanics is Hispanics whose race is identified as black only. 
Table 5

Employment Gaps Relative to Non-Hispanic Whites by Origin Area

\begin{tabular}{|c|c|c|c|c|c|c|}
\hline & \multicolumn{3}{|c|}{ Men } & \multicolumn{3}{|c|}{ Women } \\
\hline & Immigrants & $2^{\text {nd }}$ gen. & $3^{\text {rd }} \pm$ gen. & Immigrants & 2 nd gen. & $3^{\text {rd }}+$ gen. \\
\hline Mexican Americans & $0.023 * * *$ & $-0.026 * * *$ & $-0.047 * * *$ & $-0.240 * * *$ & $-0.051 * * *$ & $-0.050 * * *$ \\
\hline Cuban Americans & $-0.019 * * *$ & 0.008 & -0.040 & $-0.072 * * *$ & $0.042 * * *$ & -0.019 \\
\hline Dominican Americans & -0.036 & $-0.034^{* *}$ & $-0.061 * * *$ & $-0.125 * * *$ & -0.020 & $-0.027 * * *$ \\
\hline Puerto Ricans & $-0.140 * * *$ & $-0.097 * * *$ & $-0.092 * * *$ & $-0.191^{* * *}$ & $-0.081 * * *$ & $-0.072 * * *$ \\
\hline
\end{tabular}

$* \mathrm{p}<0.1 ; * * \mathrm{p}<0.05 ; * * * \mathrm{p}<0.01$

Note: Shown are employment gaps between the indicated group and $3^{\text {rd }}+$ generation non-Hispanic whites. For Puerto Ricans, “immigrants" are Hispanics who were born in Puerto Rico, the $2^{\text {nd }}$ generation is mainland-born Hispanics with a parent born in Puerto Rico, and the $3^{\text {rd }}+$ generation is U.S.-born Hispanics who are reported as Puerto Rican with U.S.-born parents. 
Table 6

Decomposition Results for Employment Gap between Groups of Hispanics

\begin{tabular}{|c|c|c|c|c|c|c|}
\hline & \multicolumn{2}{|c|}{$\begin{array}{c}\text { Immigrants } \\
\text { US Citizen (v. Not) }\end{array}$} & \multicolumn{2}{|c|}{$\begin{array}{c}\text { Immigrants } \\
\text { Child Arrival (v. Adult) }\end{array}$} & \multicolumn{2}{|c|}{$\begin{array}{c}2^{\text {nd }} \text { Generation } \\
\text { One FB Parent (v. Two) }\end{array}$} \\
\hline & Men & Women & Men & Women & Men & Women \\
\hline Employment gap & -0.002 & $0.174 * * *$ & $-0.009 * * *$ & $0.105^{* * *}$ & $-0.022 * * *$ & $-0.016^{*}$ \\
\hline \multicolumn{7}{|c|}{ Due to differences in means: } \\
\hline Age & $-0.018 * * *$ & $-0.006 * * *$ & $0.014^{* * *}$ & $-0.007 * * *$ & $-0.013 * * *$ & $-0.008 * * *$ \\
\hline Education & $0.007 * * *$ & $0.039 * * *$ & $0.004 * * *$ & $0.030 * * *$ & -0.0003 & $-0.006^{*}$ \\
\hline Marital status and kids & $0.005 * * *$ & $0.027 * * *$ & $-0.004 * * *$ & 0.001 & $0.008 * * *$ & $0.009 * * *$ \\
\hline Economic conditions & $-0.001 * * *$ & $-0.002 * *$ & $-0.001 *$ & $-0.003 * * *$ & $0.004 * * *$ & $0.006 * * *$ \\
\hline \multicolumn{7}{|c|}{ Due to differences in coefficients: } \\
\hline Age & -0.0001 & $-0.002 * * *$ & 0.001 & $0.006 * *$ & 0.001 & 0.003 \\
\hline Education & $-0.007 * * *$ & $-0.012^{* * *}$ & $-0.007 * * *$ & $-0.015^{* * *}$ & 0.001 & $0.001^{*}$ \\
\hline Marital status and kids & $0.022 * *$ & $0.068 * * *$ & $0.029 *$ & $0.056 * * *$ & 0.020 & -0.010 \\
\hline Economic conditions & 0.004 & 0.045 & -0.0004 & 0.012 & $0.045 * *$ & -0.035 \\
\hline Constant & -0.012 & 0.016 & $-0.044 *$ & 0.024 & $-0.088 * * *$ & 0.023 \\
\hline
\end{tabular}

$* \mathrm{p}<0.1 ; * * \mathrm{p}<0.05 ; * * * \mathrm{p}<0.01$

Note: Shown are results from Oaxaca decompositions of the employment gap. Columns 1 and 2 compare Hispanic immigrants who are naturalized citizens with those who are not. Columns 3 and 4 compare Hispanics who immigrated when age 15 or younger ("child arrival”) with those who were age 16 or older ("adult arrival”). Columns 5 and 6 compare second-generation Hispanics with one foreign-born parent with those with two foreign-born parents. 
Table 7

Employment Rate of Hispanics aged 25-34 by Immigration Generation and Time Period

\begin{tabular}{|c|c|c|c|}
\hline & Immigrant & $2^{\text {nd }}$ gen. & $3^{\text {rd }} \pm$ gen \\
\hline \multicolumn{4}{|l|}{ Men: } \\
\hline 1996-1997 & 0.893 & 0.880 & 0.850 \\
\hline 2016-2017 & 0.908 & 0.850 & 0.812 \\
\hline \multicolumn{4}{|l|}{ Women: } \\
\hline 1996-1997 & 0.485 & 0.720 & 0.655 \\
\hline 2016-2017 & 0.546 & 0.714 & 0.690 \\
\hline
\end{tabular}

Note: Shown are weighted means for people in the indicated age groups and years from the CPS. Observations are weighted using the final person weights. 
Table 8

Decomposition Results for Employment Gap among Hispanics aged 25-34 across Immigrant Generations and Time Periods

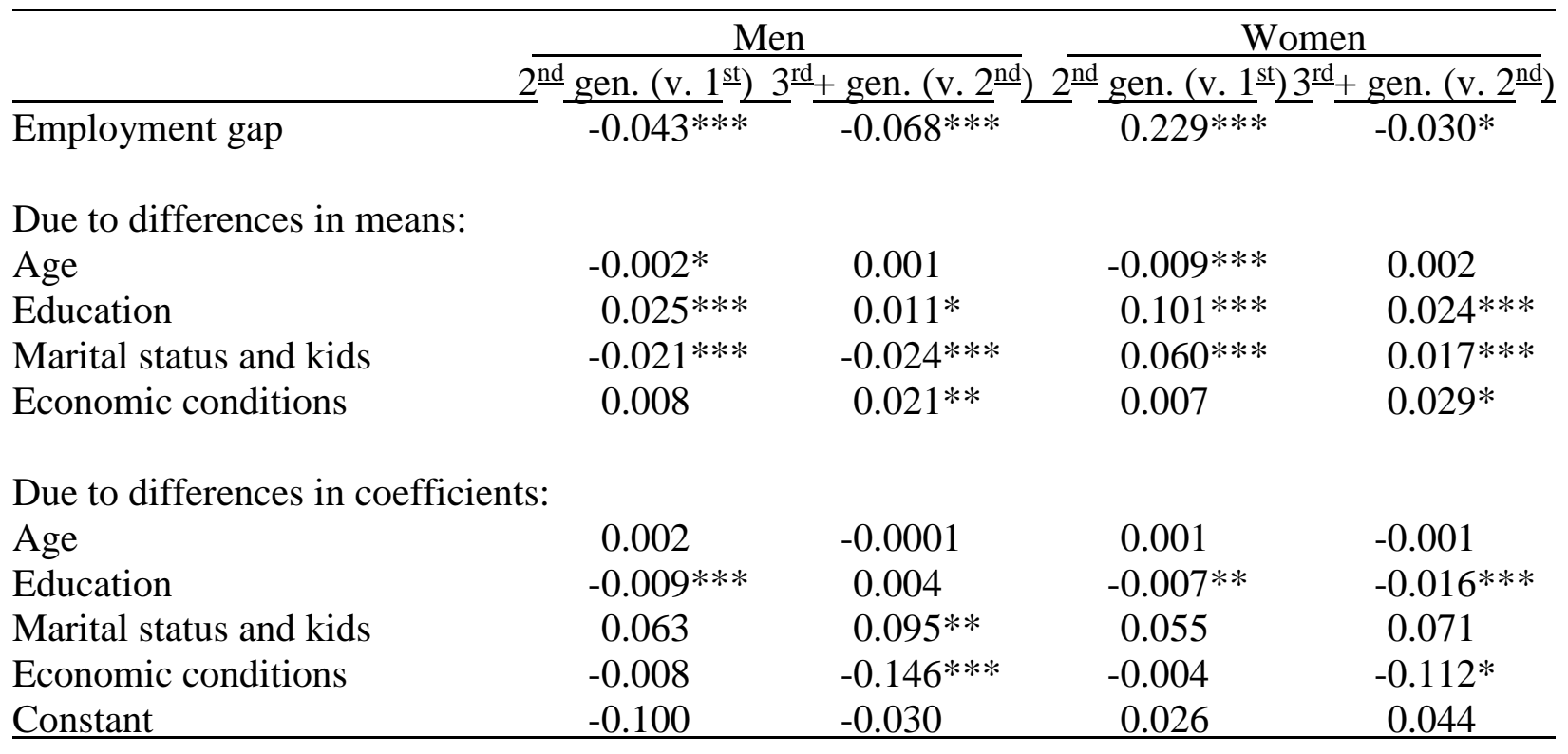

$* \mathrm{p}<0.1 ; * * \mathrm{p}<0.05 ; * * * \mathrm{p}<0.01$

Note: Shown are results from Oaxaca decompositions of the employment gap between the indicated groups. All observations are Hispanics aged 25-34. The earlier generation is from the 1996-1997 CPS, and the later generation is from the 2016-2017 CPS. 


\section{Table 9}

\section{Employment Rates in NLSY97}

\begin{tabular}{|c|c|c|c|c|c|c|}
\hline & \multicolumn{4}{|c|}{ Hispanic } & \multicolumn{2}{|c|}{ Non-Hispanic } \\
\hline & Immigrants & $2 \stackrel{\text { nd }}{ }$ gen. & $3^{\text {rd }}$ gen. & $4^{\mathrm{th}}+$ gen. & Blacks & Whites \\
\hline \multicolumn{7}{|l|}{ Men: } \\
\hline Employment rate & 0.912 & 0.817 & 0.841 & 0.765 & 0.700 & 0.861 \\
\hline Number of observations & 115 & 319 & 123 & 326 & 591 & 1275 \\
\hline \multicolumn{7}{|l|}{ Women: } \\
\hline Employment rate & 0.661 & 0.733 & 0.758 & 0.687 & 0.685 & 0.766 \\
\hline Number of observations & 150 & 318 & 93 & 276 & 678 & 1233 \\
\hline
\end{tabular}

Note: Shown are weighted means for people in round 15 of the NLSY97. Non-Hispanic whites and blacks are $3^{\text {rd }}+$ generation; Hispanics are self-identified and can be of any race. Observations are weighted using the round 15 weights. 
Table 10

Decomposition Results for Male Employment Gap Relative to Non-Hispanic Whites in NLSY97

\begin{tabular}{lccccc}
\hline & $\begin{array}{c}\text { Hispanic } \\
\text { Immigrants }\end{array}$ & $\begin{array}{c}\text { Hispanic } \\
2^{\text {nd }} \text { gen. }\end{array}$ & $\begin{array}{c}\text { Hispanic } \\
3^{\text {rd }} \text { gen. }\end{array}$ & $\begin{array}{c}\text { Hispanic } \\
4^{\text {th }}+\text { gen. }\end{array}$ & $\begin{array}{c}\text { Non-Hispanic } \\
\text { Blacks }\end{array}$ \\
\hline Employment gap & $0.050^{* * *}$ & -0.044 & -0.021 & $-0.096^{* * *}$ & $-0.162^{* * *}$ \\
Due to differences in means: & & & & & \\
Age & -0.001 & 0.001 & 0.0003 & 0.0001 & 0.0003 \\
Education & $-0.022^{* * *}$ & $-0.018^{* * *}$ & $-0.012^{* *}$ & $-0.023^{* * *}$ & $-0.025^{* * *}$ \\
Marital status and kids & -0.003 & $-0.008^{*}$ & $-0.010^{*}$ & $-0.007^{*}$ & $-0.014^{* * *}$ \\
Economic conditions & -0.014 & -0.007 & -0.007 & -0.001 & -0.003 \\
& & & & & \\
Due to differences in coefficients: & & & & & \\
Age & -0.014 & 0.005 & $0.042^{* *}$ & 0.010 & -0.065 \\
Education & 0.001 & 0.010 & $0.043^{* * *}$ & 0.016 & -0.006 \\
Marital status and kids & 0.010 & -0.006 & $-0.075^{* *}$ & 0.020 & $0.063^{*}$ \\
Economic conditions & 0.052 & $0.430^{* * *}$ & 0.127 & 0.018 & 0.096 \\
Constant & 0.041 & $-0.453^{* * *}$ & -0.127 & -0.129 & $-0.209^{* *}$ \\
\hline
\end{tabular}

$* \mathrm{p}<0.1 ; * * \mathrm{p}<0.05 ; * * * \mathrm{p}<0.01$

Note: Shown are results from Oaxaca decompositions of the employment gap between the indicated group and $3^{\text {rd }}+$ generation non-Hispanic whites. 
Table 11

Decomposition Results for Female Employment Gap Relative to Non-Hispanic Whites in NLSY97

\begin{tabular}{|c|c|c|c|c|c|}
\hline & $\begin{array}{c}\text { Hispanic } \\
\text { Immigrants }\end{array}$ & $\begin{array}{l}\text { Hispanic } \\
2^{\text {nd }} \text { gen. }\end{array}$ & $\begin{array}{l}\text { Hispanic } \\
3^{\text {rd }} \text { gen. }\end{array}$ & $\begin{array}{l}\text { Hispanic I } \\
4^{\text {th}}+\text { gen. }\end{array}$ & $\begin{array}{c}\text { Non-Hispanic } \\
\text { Blacks }\end{array}$ \\
\hline Employment gap & $-0.105 * * *$ & -0.033 & -0.008 & $-0.079 * * *$ & $-0.081 * * *$ \\
\hline \multicolumn{6}{|c|}{ Due to differences in means: } \\
\hline Age & 0.001 & 0.001 & -0.0004 & 0.002 & 0.001 \\
\hline Education & $-0.089 * * *$ & $-0.037 * * *$ & $-0.032 * * *$ & $-0.058 * * *$ & $-0.040 * * *$ \\
\hline Marital status and kids & $-0.044 * * *$ & -0.023 & 0.006 & -0.009 & -0.010 \\
\hline Economic conditions & -0.021 & -0.016 & -0.017 & -0.001 & -0.006 \\
\hline \multicolumn{6}{|c|}{ Due to differences in coefficients: } \\
\hline Age & 0.008 & 0.009 & $0.054 * *$ & $0.164 * * *$ & $0.018 *$ \\
\hline Education & 0.006 & $-0.025^{*}$ & $-0.076 * * *$ & -0.004 & 0.002 \\
\hline Marital status and kids & -0.052 & -0.079 & 0.028 & $0.100 * *$ & -0.004 \\
\hline Economic conditions & 0.131 & 0.027 & -0.106 & $0.255^{*}$ & -0.043 \\
\hline Constant & -0.045 & 0.110 & -0.135 & -0.528 & 0.0003 \\
\hline
\end{tabular}

$* \mathrm{p}<0.1 ; * * \mathrm{p}<0.05 ; * * * \mathrm{p}<0.01$

Note: Shown are results from Oaxaca decompositions of the employment gap between the indicated group and $3^{\text {rd }}+$ generation non-Hispanic whites. 


\section{Appendix Table 1}

Determinants of Employment for Men, by Race/Ethnicity and Immigrant Generation

\begin{tabular}{|c|c|c|c|c|c|}
\hline & \multicolumn{3}{|c|}{ Hispanic } & \multicolumn{2}{|c|}{ Non-Hispanic } \\
\hline & Immigrants & $2^{\text {nd }}$ gen. & $3^{\text {rd }}+$ gen. & Blacks & Whites \\
\hline Less than HS diploma & $\begin{array}{l}-0.018^{* * *} \\
(0.005)\end{array}$ & $\begin{array}{l}-0.100^{* * * *} \\
(0.008)\end{array}$ & $\begin{array}{l}-0.143 * * * \\
(0.015)\end{array}$ & $\begin{array}{l}-0.189 * * * \\
(0.009)\end{array}$ & $\begin{array}{l}-0.163 * * * \\
(0.007)\end{array}$ \\
\hline Some college & $\begin{array}{c}0.002 \\
(0.004)\end{array}$ & $\begin{array}{l}0.041^{* * *} \\
(0.005)\end{array}$ & $\begin{array}{l}0.041^{* * *} \\
(0.010)\end{array}$ & $\begin{array}{l}0.072 * * * \\
(0.003)\end{array}$ & $\begin{array}{l}0.034 * * * \\
(0.002)\end{array}$ \\
\hline College graduate & $\begin{array}{l}0.023^{* * *} \\
(0.006)\end{array}$ & $\begin{array}{l}0.087^{* * *} \\
(0.005)\end{array}$ & $\begin{array}{l}0.117^{* * *} \\
(0.012)\end{array}$ & $\begin{array}{l}0.161^{* * *} \\
(0.006)\end{array}$ & $\begin{array}{l}0.089 * * * \\
(0.004)\end{array}$ \\
\hline Married & $\begin{array}{l}0.045^{* * *} \\
(0.005)\end{array}$ & $\begin{array}{l}0.122^{* * *} \\
(0.008)\end{array}$ & $\begin{array}{l}0.154^{* * *} \\
(0.008)\end{array}$ & $\begin{array}{l}0.172^{* * *} \\
(0.007)\end{array}$ & $\begin{array}{l}0.115^{* * *} \\
(0.003)\end{array}$ \\
\hline Divorced & $\begin{array}{c}0.011^{*} \\
(0.006)\end{array}$ & $\begin{array}{l}0.060^{* * *} \\
(0.010)\end{array}$ & $\begin{array}{l}0.090^{* * *} \\
(0.009)\end{array}$ & $\begin{array}{l}0.075^{* * *} \\
(0.007)\end{array}$ & $\begin{array}{l}0.038^{* * * *} \\
(0.002)\end{array}$ \\
\hline Widowed & $\begin{array}{l}-0.042^{* *} \\
(0.016)\end{array}$ & $\begin{array}{l}-0.002 \\
(0.026)\end{array}$ & $\begin{array}{l}-0.002 \\
(0.033)\end{array}$ & $\begin{array}{c}0.021^{* *} \\
(0.009)\end{array}$ & $\begin{array}{l}-0.026^{* * *} \\
(0.007)\end{array}$ \\
\hline Separated & $\begin{array}{c}0.007 \\
(0.007)\end{array}$ & $\begin{array}{l}0.031^{* *} \\
(0.013)\end{array}$ & $\begin{array}{l}0.042^{* * *} \\
(0.012)\end{array}$ & $\begin{array}{l}0.055^{* * *} \\
(0.006)\end{array}$ & $\begin{array}{l}0.025^{* * *} \\
(0.005)\end{array}$ \\
\hline Number of kids age $6+$ at home & $\begin{array}{l}0.005^{* * *} \\
(0.001)\end{array}$ & $\begin{array}{l}0.012^{* * *} \\
(0.003)\end{array}$ & $\begin{array}{l}0.014^{* * *} \\
(0.002)\end{array}$ & $\begin{array}{l}0.012^{* * *} \\
(0.001)\end{array}$ & $\begin{array}{l}0.016^{* * *} \\
(0.001)\end{array}$ \\
\hline Number of kids under 6 at home & $\begin{array}{c}0.004^{* *} \\
(0.001)\end{array}$ & $\begin{array}{l}0.011^{* * *} \\
(0.004)\end{array}$ & $\begin{array}{l}-0.002 \\
(0.003)\end{array}$ & $\begin{array}{l}-0.001 \\
(0.003)\end{array}$ & $\begin{array}{c}0.001 \\
(0.001)\end{array}$ \\
\hline State unemployment rate & $\begin{array}{l}-0.012 * * * \\
(0.002)\end{array}$ & $\begin{array}{l}-0.009 * * * \\
(0.002)\end{array}$ & $\begin{array}{l}-0.010^{* *} \\
(0.005)\end{array}$ & $\begin{array}{l}-0.023^{* * *} \\
(0.004)\end{array}$ & $\begin{array}{l}-0.014 * * * \\
(0.001)\end{array}$ \\
\hline
\end{tabular}

${ }^{*} \mathrm{p}<0.1 ; * * \mathrm{p}<0.05 ; * * * \mathrm{p}<0.01$

Note: Shown are estimated coefficients from linear probability regressions with employment as the dependent variable. Regressions also include dummy variables for single year of age and for time (month*year). Observations are weighted using the final person weights, and standard errors are clustered on state. 
Appendix Table 2

Determinants of Employment for Women, by Race/Ethnicity and Immigrant Generation

\begin{tabular}{|c|c|c|c|c|c|}
\hline & \multicolumn{3}{|c|}{ Hispanic } & \multicolumn{2}{|c|}{ Non-Hispanic } \\
\hline & Immigrants & $2^{\text {nd }}$ gen. & $3^{\text {rd }}+$ gen. & Blacks & Whites \\
\hline Less than HS diploma & $\begin{array}{l}-0.107 * * * \\
(0.006)\end{array}$ & $\begin{array}{l}-0.176^{* * * *} \\
(0.006)\end{array}$ & $\begin{array}{l}-0.225 * * * \\
(0.011)\end{array}$ & $\begin{array}{l}-0.217^{* * *} \\
(0.005)\end{array}$ & $\begin{array}{l}-0.239 * * * \\
(0.006)\end{array}$ \\
\hline Some college & $\begin{array}{l}0.073^{* * *} \\
(0.007)\end{array}$ & $\begin{array}{l}0.090^{* * *} \\
(0.009)\end{array}$ & $\begin{array}{l}0.071^{* * *} \\
(0.006)\end{array}$ & $\begin{array}{l}0.090^{* * *} \\
(0.003)\end{array}$ & $\begin{array}{l}0.062 * * * \\
(0.003)\end{array}$ \\
\hline College graduate & $\begin{array}{l}0.096^{* * *} \\
(0.004)\end{array}$ & $\begin{array}{l}0.163^{* * *} \\
(0.010)\end{array}$ & $\begin{array}{l}0.156^{* * *} \\
(0.007)\end{array}$ & $\begin{array}{l}0.197 * * * \\
(0.006)\end{array}$ & $\begin{array}{l}0.132 * * * \\
(0.005)\end{array}$ \\
\hline Married & $\begin{array}{l}-0.123^{* * *} \\
(0.015)\end{array}$ & $\begin{array}{l}-0.028^{* *} \\
(0.012)\end{array}$ & $\begin{array}{c}0.021 \\
(0.014)\end{array}$ & $\begin{array}{l}0.051^{* * * *} \\
(0.005)\end{array}$ & $\begin{array}{l}-0.008 * \\
(0.004)\end{array}$ \\
\hline Divorced & $\begin{array}{l}0.058^{* * *} \\
(0.009)\end{array}$ & $\begin{array}{l}0.065^{* * *} \\
(0.014)\end{array}$ & $\begin{array}{l}0.074^{* * *} \\
(0.010)\end{array}$ & $\begin{array}{l}0.061^{* * *} \\
(0.003)\end{array}$ & $\begin{array}{l}0.039 * * * \\
(0.003)\end{array}$ \\
\hline Widowed & $\begin{array}{l}-0.065 * * * \\
(0.007)\end{array}$ & $\begin{array}{l}-0.060^{* * *} \\
(0.016)\end{array}$ & $\begin{array}{l}-0.039 * \\
(0.021)\end{array}$ & $\begin{array}{l}-0.060^{* * *} \\
(0.008)\end{array}$ & $\begin{array}{l}-0.063 * * * \\
(0.005)\end{array}$ \\
\hline Separated & $\begin{array}{l}0.045^{* * *} \\
(0.010)\end{array}$ & $\begin{array}{l}0.031^{* *} \\
(0.015)\end{array}$ & $\begin{array}{c}0.008 \\
(0.015)\end{array}$ & $\begin{array}{c}0.006 \\
(0.006)\end{array}$ & $\begin{array}{l}-0.011 \\
(0.007)\end{array}$ \\
\hline Number of kids age $6+$ at home & $\begin{array}{l}-0.020 * * * \\
(0.002)\end{array}$ & $\begin{array}{l}-0.011^{* * *} \\
(0.002)\end{array}$ & $\begin{array}{l}-0.014 * * * \\
(0.002)\end{array}$ & $\begin{array}{l}-0.002 \\
(0.001)\end{array}$ & $\begin{array}{l}-0.020 * * * \\
(0.001)\end{array}$ \\
\hline Number of kids under 6 at home & $\begin{array}{l}-0.135^{* * *} \\
(0.003)\end{array}$ & $\begin{array}{l}-0.089^{* * *} \\
(0.003)\end{array}$ & $\begin{array}{l}-0.100^{* * *} \\
(0.006)\end{array}$ & $\begin{array}{l}-0.060^{* * *} \\
(0.002)\end{array}$ & $\begin{array}{l}-0.122^{* * *} \\
(0.003)\end{array}$ \\
\hline State unemployment rate & $\begin{array}{l}-0.007 \\
(0.005)\end{array}$ & $\begin{array}{l}-0.004^{* *} \\
(0.002)\end{array}$ & $\begin{array}{l}-0.010 * \\
(0.006)\end{array}$ & $\begin{array}{l}-0.018^{* * *} \\
(0.004)\end{array}$ & $\begin{array}{l}-0.017 * * * \\
(0.003)\end{array}$ \\
\hline
\end{tabular}

${ }^{*} \mathrm{p}<0.1 ; * * \mathrm{p}<0.05 ; * * * \mathrm{p}<0.01$

Note: Shown are estimated coefficients from linear probability regressions with employment as the dependent variable. Regressions also include dummy variables for single year of age and for time (month*year). Observations are weighted using the final person weights, and standard errors are clustered on state. 